\title{
Fundamental factors on the behaviour of bagasse ash stabilized organic soil
}

\author{
John Tri Hatmoko and Hendra Suryadharma \\ Program Studi Teknik Sipil , Universitas Atma Jaya Yogyakarta, Jln. Babarsari No. 44 Yogyakarta
}

\begin{abstract}
A series of experimental programs was undertaken to investigate mechanical behaviour of bagasse ash stabilized organic soil. Preliminary experiment was done to verify the chemical and physical characteristics of bagasse ash and organic soil. The following experiment was then performed to study the improvement of unconfined compression strength of bagasse ash stabilized organic soil. In this research, three different organic soils and four different bagasse ashes were used. The soil was mixed with 10,20 and $30 \%$ bagasse ash, then a set of unconfined compression tests were performed. In general, the results indicate that the unconfined compression strength of stabilized soil improve proportional to the percentage of bagasse ash. And, the quick lime content $(\mathrm{CaO})$, ratio between quick lime and silica $\left(\mathrm{CaO} / \mathrm{SiO}_{2}\right)$, and ratio between quick lime and the sum of silica and alumina $\left\{\mathrm{CaO} /\left(\mathrm{SiO}_{2}+\mathrm{Al}_{2} \mathrm{O}_{3}\right)\right\}$ were the fundamental factors affecting the improvement of bagasse ash stabilized soil unconfined compression strength. The significant improvement occurs on $0.25<\left(\mathrm{CaO} / \mathrm{SiO}_{2}\right)<1.00$, and $0.20<\left(\mathrm{CaO} /\left(\mathrm{SiO}_{2}+\mathrm{Al}_{3} \mathrm{O}_{3}\right)<0.67\right.$. In contrast, organic content decreased unconfined compression, and maximum dry density (MDD) of stabilized soil. The addition of bagasse to the organic soil, however, does not significantly improve the unconfined compression strength, then addition of 6,8 , and $10 \%$ calcium carbide residue (CCR) was performed to the bagasse ash stbilized organic soil to get better engineering performance of stabilized soil. For $9 \%$ CCR, $\mathrm{qu}_{\mathrm{u}}$ improve from 93 to $208 \mathrm{kPa}$.
\end{abstract}

\section{Introduction}

Organic soil formed from weathered plants has usually low shear strength and high compressibility, then it is problematic directly used for construction projects. Practically, in construction project, the organic soil is removed and replaced by crushed stones or preloaded to improve its engineering properties. Soil improvement by admixtures such as cement, lime, calcium carbide, fly ash, rice husk ash, and bagasse ash is a good alternative [1-7]. The improvement is also popular as chemical stabilization.

Chemical stabilization of soft soil such as clay was done by addition of chemical admixtures into the soil to improve its shear strength and stiffness. Moreover, to reduce the water content of soft soil - high water content to its optimum moisture content is difficult and time consuming, addition of chemical binders is then preferable. Therefore, addition of chemical admixtures decreases the water content and improves shear strength and stiffness of soft soil. Cement, lime, fly ash, risk husk ash and bagasse ash are common admixtures that have been used as binder materials. The use of bagasse ash is interesting because it is a fine residue collected from sugar factory [3].
Bagasse ash and its combination with lime or carbide lime has been shown to successfully improve shear strength of clay as inorganic soil [8-10]. However, it is not enough literatures regarding the use of bagasse ash for stabilizing agents of organic soil. It was found that chemical stabilization of organic soil is more difficult compared to that of organic soil such as clay [11-14]. The objectives of this research was : to verify whether the engineering properties of organic soil can be improved by addition of bagasse ash; and if it was successfully performed, to investigate the improvement of unconfined compression strength of bagasse ash stabilized organic soil; and to study the important factors influencing the process of soil improvement.

A series of reactions take place resulting in dissociation of quick lime in the binder agents and the formation of calcium silicate hydrate and calcium aluminate silicate hydrate in the form of pozzolanic gels, if the admixtures such as cement, lime, fly ash, rice husk ash and bagasse ash are mixed with watered-soil. The reactions are called pozzolanic reactions. The improvement of shear strength of chemically stabilized soft soil was noted to be significantly related to the product of pozzolanic reactions. The short term product is the formation of calcium silicate hydrate whereas long term product is the production of calcium aluminate silicate hydrate. Contributions of those reactions to the

\footnotetext{
$\bar{*}$ Corresponding author: john@mail.uajy.ac.id
} 
improvement engineering behaviour of soft soil occurs in two ways. The first way is reduction of plasticity of soft soils due to the exchange of calcium ions $\left(\mathrm{Ca}^{+2}\right)$ with $\mathrm{K}^{+}$and $\mathrm{Na}^{+}$in the soil. Second, the formation of calcium silicate hydrate and calcium-aluminate silicate hydrate due to pozzolanic reactions bind the solid particles, and hence it produces the stronger soil. For organic soil, however, the pozzolanic reactions slowly occurs because of absorbing pozzolanic material by the organic compound [13], [15,16]. The other literature [14] said that organic matter can change the structure of calcium silicate hydrate gel to delay the shear strength improvement of stabilized soil.

\section{Materials and Methods}

\subsection{Organic Soils}

Organic soils were taken from three different sites: Ketapang Regency ( X), Wates ( Y), and Kalasan (Z). The result sieve analysis and hydrometer, Atterberg limits, and compaction tests is summarized in Table 1.

Table 1. Soils parameters

\begin{tabular}{|c|c|c|c|}
\hline \multirow{2}{*}{ Soils parameters } & \multicolumn{3}{|c|}{ Soils } \\
\cline { 2 - 4 } & $\mathrm{X}$ & $\mathrm{Y}$ & $\mathrm{Z}$ \\
\hline Liquid Limit (LL),(\%) & 52 & 35 & 56 \\
\hline Plastic Limits (PL),(\%) & 76 & 39 & 74 \\
\hline Plasticity Index (PI), (\%) & 24 & 4 & 18 \\
\hline $\mathrm{d}<0.075 \mathrm{~mm}),(\%)$ & 27 & 78 & 93 \\
\hline $\mathrm{d}<0.002 \mathrm{~mm},(\%)$ & 16 & 37 & 57 \\
\hline Organic Content (OC), (\%) & 25 & 13 & 18 \\
\hline Spec. Gravity (G) & 2.47 & 2.52 & 2.25 \\
\hline Natural w. content (w),(\%) & 53 & 22 & 29 \\
\hline Opt. w. content,(OMC),(\%) & 45 & 25 & 31 \\
\hline $\begin{array}{c}\text { Max. dry density (MDD), } \\
\left(\mathrm{kN} / \mathrm{m}^{3}\right)\end{array}$ & 11.7 & 16.3 & 14.8 \\
\hline USCS Classification & $\mathrm{OH}$ & $\mathrm{OL}$ & $\mathrm{OH}$ \\
\hline
\end{tabular}

The soil samples were collected from the depth of 0.75 to 1 meter underground surface. The compaction curves of the soils specimens were bell-shaped curves with maximum dry density depends on organic content. The more organic content, the less the maximum dry density of soil sample. The same evidence can be seen on the specific gravity.

\subsection{Bagasse Ash and Calcium Carbide}

Bagasse ash was collected from Madukismo Sugar factory, then it was re-burnt with 4(four) different temperatures. The burning temperatures $50^{\circ} \mathrm{C}$ (B), $100^{\circ} \mathrm{C}(\mathrm{C})$, and $150^{\circ} \mathrm{C}(\mathrm{D})$, and $\mathrm{A}$ is the original bagasse ash. The chemical content, degree of acidity $(\mathrm{pH})$, and specific gravity $(\mathrm{G})$ of bagasse ashes is summarized in Table 2.
Table 2. Properties of Bagasse Ash

\begin{tabular}{|c|l|l|l|l|}
\hline \multirow{2}{*}{$\begin{array}{c}\text { Bagasse Ash } \\
\text { Properties }\end{array}$} & \multicolumn{4}{|c|}{ Bagasse Ashes } \\
\cline { 2 - 5 } & A & B & C & D \\
\hline Silica $\left(\mathrm{SiO}_{2}\right),(\%)$ & 8.2 & 24.1 & 37.0 & 40.6 \\
\hline Alumina $\left(\mathrm{Al}_{2} \mathrm{O}_{3}\right),(\%)$ & 7.1 & 15.3 & 18.6 & 16.7 \\
\hline Ferrit $\left(\mathrm{Fe}_{2} \mathrm{O}_{3}\right),(\%)$ & 2.9 & 10.7 & 3.7 & 7.8 \\
\hline Quick lime $(\mathrm{CaO}),(\%)$ & 9.4 & 26.1 & 5.9 & $\left.9.6^{* *}\right)$ \\
\hline Magnesium $(\mathrm{MgO}),(\%)$ & 1.5 & 5.5 & 1.3 & 4.5 \\
\hline $\mathrm{CaO} / \mathrm{SiO}_{2}$ & 0.182 & 1.08 & 0.159 & 0.236 \\
\hline $\mathrm{CaO} /\left(\mathrm{SiO}_{2}+\mathrm{Al}_{2} \mathrm{O}_{3}\right)$ & 0.15 & 0.66 & 0.11 & 0.17 \\
\hline Loss of ignition $(\mathrm{LOI}),(\%)$ & 45.5 & 21.8 & 9.5 & 8.7 \\
\hline$\left(\mathrm{SiO}_{2}\right)+\left(\mathrm{Al}_{2} \mathrm{O}_{3}\right)+\left(\mathrm{Fe}_{2} \mathrm{O}_{3}\right)$, & 18.2 & 51.1 & 60.1 & 75.1 \\
$(\%)$ & & $\left.{ }^{*}\right)$ & & $\left.{ }^{* *}\right)$ \\
\hline Degree of acidity $(\mathrm{pH})$ & 10.2 & 11.3 & 11.9 & 12.2 \\
\hline Specific $\mathrm{Gravity}(\mathrm{G})$ & 2.3 & 2.35 & 2.41 & 2.45 \\
\hline
\end{tabular}

Note: $\left.{ }^{*}\right)$ equivalent to $\mathrm{C}$ class Fly Ash: $\mathrm{CaO}>20 \%,\left(\mathrm{SiO}_{2}\right)^{+}$ $\left.\left(\mathrm{Al}_{2} \mathrm{O}_{3}\right)+\left(\mathrm{Fe}_{2} \mathrm{O}_{3}\right),(50-60 \%) .{ }^{* *}\right)$ equivalent to $\mathrm{F}$ class Fly Ash $\mathrm{CaO}<10 \%,\left(\mathrm{SiO}_{2}\right)+\left(\mathrm{Al}_{2} \mathrm{O}_{3}\right)+\left(\mathrm{Fe}_{2} \mathrm{O}_{3}\right)>75(\%)$.

Bagasse ash A (original bagasse ash) has the highest carbon content $(\mathrm{LOI}=45.5 \%)$ compared to the others, and bagasse $\mathrm{D}$ has the lowest carbon content $(\mathrm{LOI}=8.7 \%$ ). Similar pattern can be seen on the ratio between quick lime $(\mathrm{CaO})$ and silica $\left(\mathrm{SiO}_{2}\right)$.

Calcium carbide residue (CCR) were taken from acetylene gas factory, its chemical content and physical properties are: $\mathrm{CaO}(62.3 \%), \quad \mathrm{SiO}_{2} \quad(0.23 \%), \quad \mathrm{Al}_{2} \mathrm{O}_{3}$ (2.21\%), $\mathrm{MgO}$ (7.98\%), $\mathrm{Fe}_{2} \mathrm{O}_{3}(2.09 \%), \mathrm{d}<0.075 \mathrm{~mm}$ $(98.29 \%)$, and specific gravity $(2.45)$. The dosage of CCR 6,8 , and $10 \%$ were added to bagasse ash- organic soil mixture, and tested on unconfined compression apparatus.

\subsection{Unconfined Compression}

Unconfined compression tests were performed on: original organic soil specimens ( $\mathrm{X}, \mathrm{Y}, \mathrm{Z})$; bagasse ash soil mixtures and bagasse ash-calcium carbide-stabilized soil following ASTM D5102. In this test, 0,20\% per minute strain rate were used which is usual for stabilized organic soil [17]. The specimens were prepared for soilbagasse ash mixing, and soil-bagasse ash-calcium carbide. First, dry soil and dry bagasse ash with proportion of 10,20 , and $30 \%$ on dry weight basis, and the amount water required were added. Subsequently, 6, 8 , and $10 \%$ of calcium carbide were added on the best bagasse ash-soil mixture obtained from the previous tests. Finally, unconfined compression tests were performed on the soils- bagasse ash-calcium carbide mixture.

\section{Results and Discussions}

\subsection{Bagasse Ash - Soil Mixtures}

By using test procedures discussed in the previous section, organic soils $\mathrm{X}, \mathrm{Y}$ and $\mathrm{Z}$ were mixed with bagasse ashes $\mathrm{A}, \mathrm{B}, \mathrm{C}$ and $\mathrm{D}$ with the proportion of 10 , 20 , and $30 \%$ dry weight basis. Figures $1-3$, are the results of unconfined compression tests of bagasse ashsoil mixtures. 


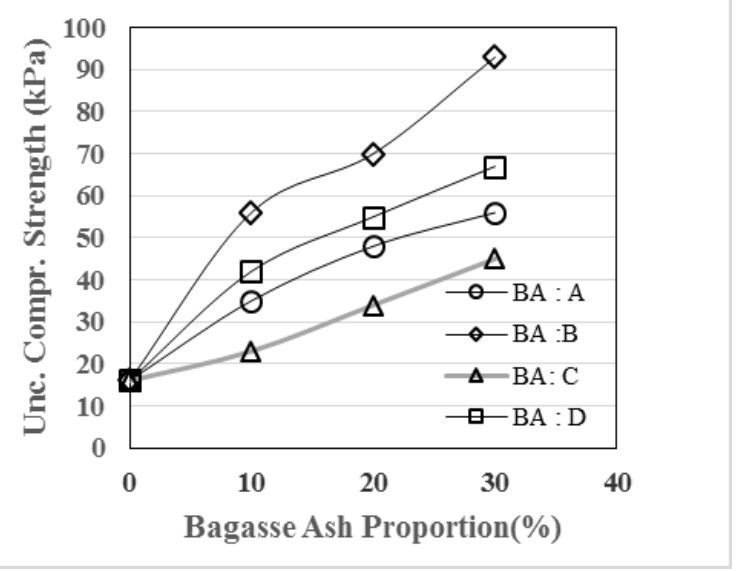

Note : $\mathrm{BA}=$ Bagasse Ash

Fig. 1. Unconfined Compression Strength of Soil X

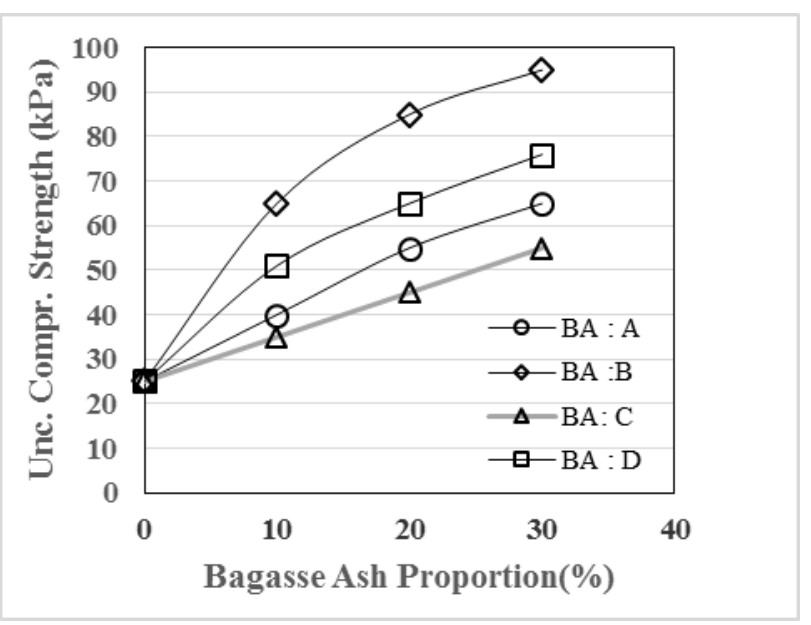

Fig. 2. Unconfined Compression Strength of Soil Y

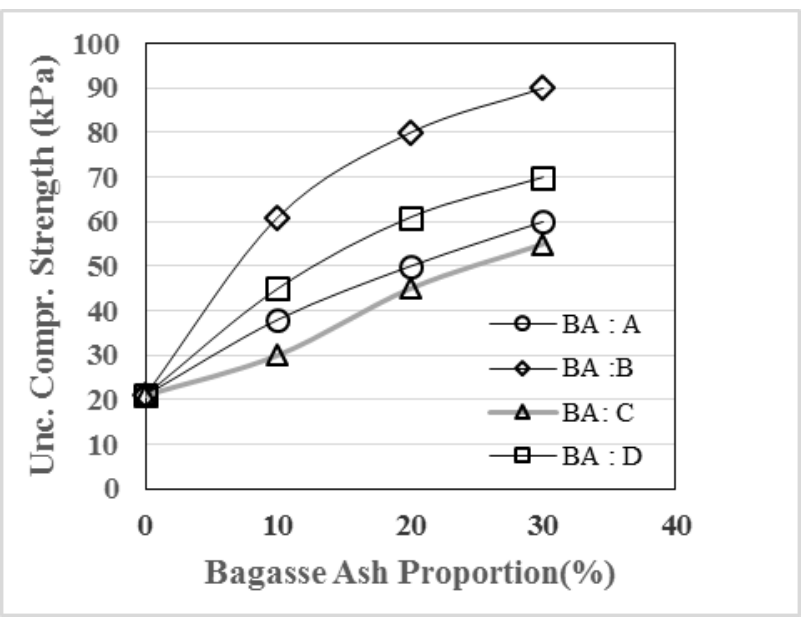

Fig. 3. Unconfined Compression Strength of Soil Z

In general, unconfined compression strength $\left(\mathrm{q}_{\mathrm{u}}\right)$ of all stabilized soil improve proportional with the increase of bagasse ash percentage even though the improvement is not significant. However, $\mathrm{CaO}$ content in the bagasse ash is significant factor affecting the improvement of $\mathrm{q}_{\mathrm{u}}$ due to self pozzolanic reaction. For example, unconfined compression strength of $\mathrm{Z}$ organic stabilized soil with $\mathrm{C}$ bagasse ash improves from 21 to $30 \mathrm{kPa}$ ( bagasse ash from $0-10 \%$ ) while with $\mathrm{B}$ bagasse ash the $\mathrm{q}_{\mathrm{u}}$ improves significantly from 21 to $61 \mathrm{kPa}$.

Original unconfined compression strength of the soil samples depends on the organic content. The higher organic content (OC), the lesser the unconfined compression strength. Organic soil Y with $13 \%$ OC, its original $\mathrm{q}_{\mathrm{u}}$ is $25 \mathrm{kPa}$ whereas unconfined compression strength of soils $\mathrm{X}(\mathrm{OC}=25 \%)$ and $\mathrm{Z}(\mathrm{OC}=18 \%)$ are 16 and $21 \mathrm{kPa}$. The unconfined compression strength of all soil specimens proportional to their maximum dry density.

\subsection{Effects of Bagasse Ash Characteristics}

Some characteristics of bagasse that should be taken into consideration are : the degree of acidity $(\mathrm{pH})$, loss of ignition (LOI), ratio between quick lime and silica ( $\left.\mathrm{CaO} / \mathrm{SiO}_{2}\right)$, and the ratio between quick lime and silica + alumina $\left[\mathrm{CaO} /\left(\mathrm{SiO}_{2}+\mathrm{Al}_{2} \mathrm{O}_{3}\right)\right]$. Those fundamental characteristics are considered to improve unconfined compression strength of bagasse ash stabilized organic soils.

\subsubsection{Effects of the degree of acidity $(p H)$}

Behaviour of bagasse ash stabilized organic soil is not rely on the degree of acidity $(\mathrm{pH})$ of the soil samples (Fig.4). It can be shown that the trend of unconfined compression strength is inconsistent with $\mathrm{pH}$. It is different from [18], accordingly significant improvement of unconfined compression strength of blast furnace slag stabilized organic soil occur when $\mathrm{pH}$ is higher than 5 .

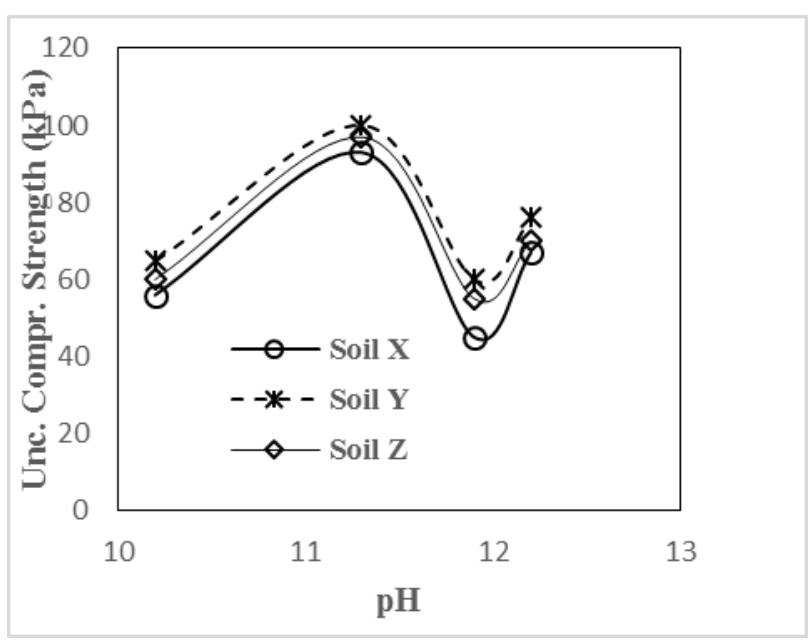

Fig. 4. Relations between Unc. Cmpr. Strength and $\mathrm{pH}$

Unconfined compression strength of stabilized soils, moreover, is not dependent on loss of ignition (LOI) of stabilizing agents. For bagasse ash A ( $\mathrm{LOI}=45.5 \%)$, $\mathrm{B}(\mathrm{LOI}=26.8 \%), \mathrm{C}(\mathrm{LOI}=9.5 \%)$, and $\mathrm{D}(4.7 \%)$ on soil $\mathrm{X}$, for example, their unconfined compression strength are $56,93,45$ and $67 \mathrm{kPa}$ respectively. 


\subsubsection{Effects of $\mathrm{CaO} / \mathrm{SiO}_{2}$}

Previous discussion stated that unconfined compression strength of bagasse ash stabilized soil was strongly affected by $\mathrm{CaO}$ content in the admixture, with coefficient of correlation between $0.957-0.995$. Similarly, $\mathrm{CaO} / \mathrm{SiO}_{2}$, also significantly contribute unconfined compression strength of stabilized soil (Fig.5). Fig.5 represents the relations between unconfined compression strength and $\mathrm{CaO} / \mathrm{SiO}_{2}$ of $30 \%$ bagasse ash stabilized soil. The improvement of $\mathrm{q}_{u}$ due to $\mathrm{CaO} / \mathrm{SiO}_{2}$ for three soils ( $\mathrm{X}, \mathrm{Y}$, and $\mathrm{Z}$ ) has the same trends with strong correlation (0.966). The dramatic improvement of unconfined compression occur on 0.25 $<\mathrm{CaO} / \mathrm{SiO}_{2}<1.00$. Even though the trend of qu improvement of three soils are similar, Y organic soil has the highest value of unconfined compression strength. It happens because of the highest $\mathrm{CaO}$ content on $\mathrm{Y}$ soil. The same behaviour occur on the others bagasse ash dosage (10, and 20\%).

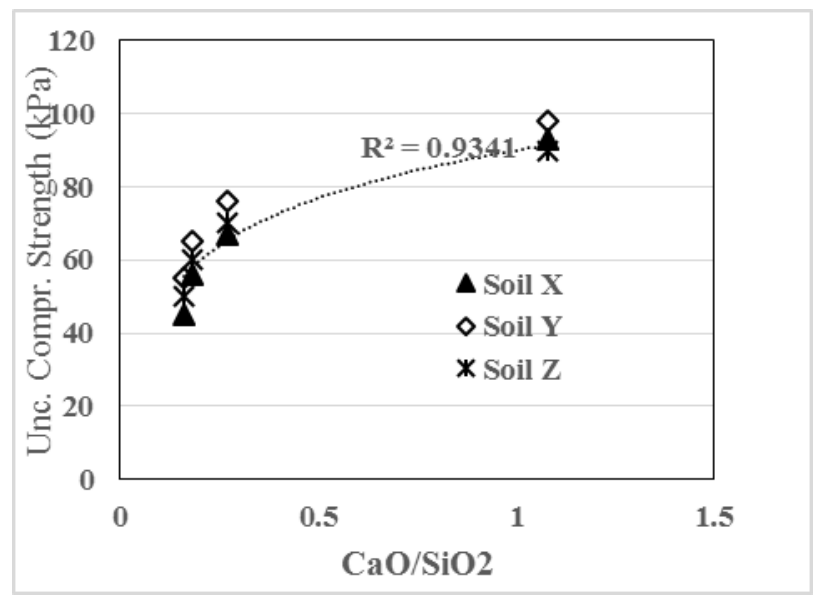

Fig. 5. Relations between Unc. Cmpr. Strength and $\mathrm{CaO} / \mathrm{SiO}_{2}$

Fig. 6 shows that $\mathrm{CaO} /\left(\mathrm{SiO}_{2}+\mathrm{Al}_{2} \mathrm{O}_{3}\right)$ is important variable influencing unconfined compression strength of bagasse ash organic soils prepared with $\mathrm{X}, \mathrm{Y}$ and $\mathrm{Z}$ soil samples. The improvement of unconfined compression strength are shown when $0.2<\mathrm{CaO} /\left(\mathrm{SiO}_{2}+\mathrm{Al}_{2} \mathrm{O}_{3}\right)<$ 0.67. The $\mathrm{q}_{\mathrm{u}}$ and $\mathrm{CaO} /\left(\mathrm{SiO}_{2}+\mathrm{Al}_{2} \mathrm{O}_{3}\right)$ of stabilized soil is strongly correlated with coefficient correlation of 0.962 . The trends of all soil samples show similarity even though Y soil specimens indicates the highest value.

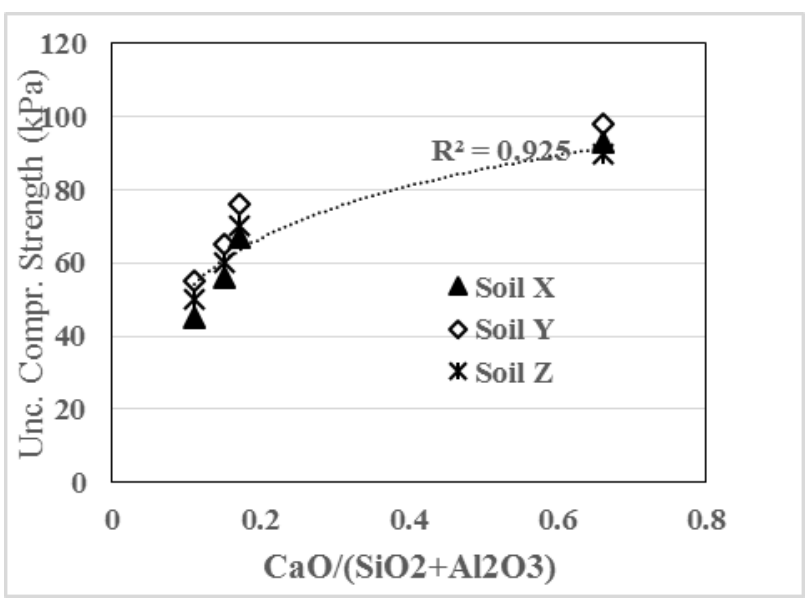

Fig. 6. Relations between Unc. Cmpr. Strength and $\mathrm{CaO} /\left(\mathrm{SiO}_{2}+\mathrm{Al}_{2} \mathrm{O}_{3}\right)$

\subsection{Effects of OC and PI of Soils}

Effects of organic content (OC) on soil to unconfined compression strength of bagasse ash stabilized soils specimens was shown on Fig. 7. The figure indicates that qu of soil specimens were reciprocally affected by organic content. The unconfined compression decreades linierly with the improvement of organic content. Similar behaviour also occur on the effects of plasicity index (PI) of soil specimens to the unconfined compression strength. As PI decreased, the $q_{u}$ of soil specimens increased (Fig. 8). The inverse relationship between $\mathrm{q}_{\mathrm{u}}$ and $\mathrm{CO}$ reflects that solids part of soils is stronger than organic content.

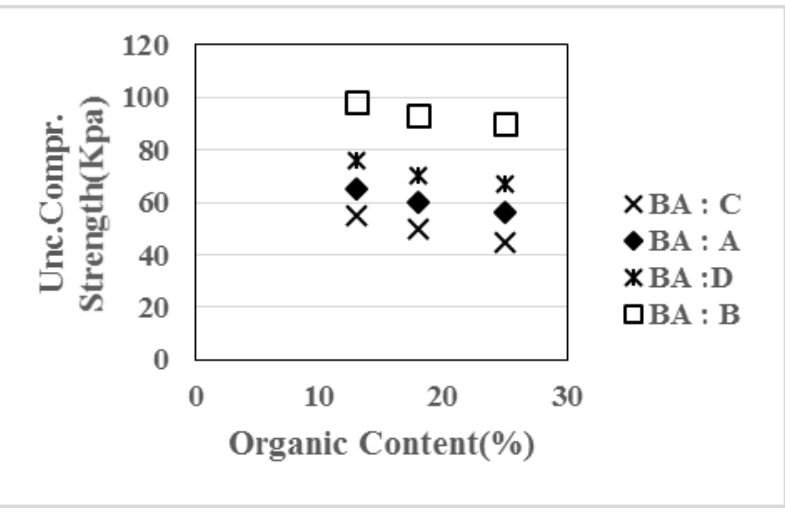

Fig. 7. Relations between Unc. Cmpr. Strength and Organic Content 


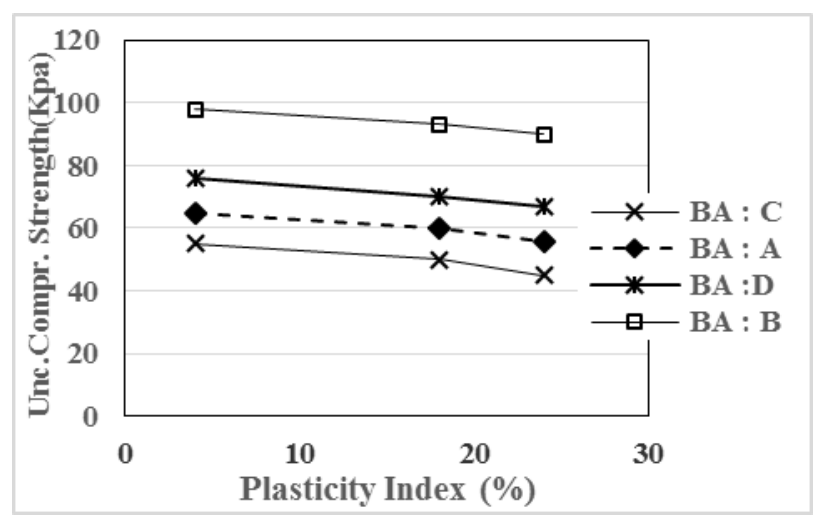

Fig. 8. Relations between Unc. Compr. Strength and Platicity Index

\subsection{Calcium Carbide (CCR) - Bagasse Ash - Soil Mixtures}

To get beter engineering performance of bagasse ash stabilized organic soils, 6,8 , and $10 \%$ were added to $30 \%$ bagasse ash - soil mixutres. CCR bagasse ash and soil were mixed in dry condition, then water were added upto the optimum water content. The samples, were prepared in the PVC pipe with a diameter $10 \mathrm{~cm}$, and 20 $\mathrm{cm}$ height, then they are compacted according to standard Proctor test. The compacted samples were cured in 7 days before unconfined compression tests were performed. Prior to addition of CCR to $30 \%$ bagasse ash stabilized soil, unconfined compression strength of soil, $\mathrm{X}, \mathrm{Y}$ and $\mathrm{Z}$ are 93,95 and $90 \mathrm{kPa}$. After 6,8 , and $10 \%$ of calcium carbide were added to $\mathrm{X}$ stabilized soil, the compression strength increased to 127 (37\%-gain) , 189 (103\% - gain) and $195 \mathrm{kPa}(110 \%$ gain). Addition the same proportion of $\mathrm{CCR}$ to $\mathrm{Y}$ stabilized soil, unconfined compression strength improve to $135 \mathrm{kPa}$ (42\%- gain), 201(112\% -gain), and $206 \mathrm{kPa}$ (117\% - gain). Addition of $6 \%$ CCR to Z stabilized soil, unconfined compression strength improve to $120 \mathrm{kPa}$, $181 \mathrm{kPa}$ for $8 \% \mathrm{CCR}$, and $188 \mathrm{kPa}$ for $10 \%$ addition of CCR ( Fig. 9). Those significant improvement of unconfined compression strength is basically due to intensity of pozzolanic reactions. Addition more $\mathrm{CaO}$ which is huge proportion on calcium carbide to the soil, formation of both calcium sylicate hydrate $(\mathrm{CSH})$ and calcium sylicate aluminat hydrate $(\mathrm{CSAH})$ that also called as pozzolanic reaction is intensively happens. These formation result on improvement of strength and stiffness stabilized soils. $\mathrm{h}$

\section{Conclusions}

The purpose of this research were to investigate the effects of bagasse ash addition to unconfined compression strength $\left(\mathrm{q}_{\mathrm{u}}\right)$ of organic soil, and to study some main factors influencing the engineering behavior of bagasse ash organic soil mixtures. Three organic soils and four bagasse ashes were used in this research. The following conclusions can be drawn from the study:
1. Unconfined compression strength of organic soils can be improved by adding bagasse ash. However, the precentage of improvement relies on the type of organic soils and characteristics of bagasse ashes. Significant improvement of unconfined compression strength was occurred on soil $\mathrm{Y}$, whereas bagasse ash $\mathrm{B}$ was the best admixture for organic soils. The qu of bagasse ash B- Y organic soil mixtures increased from $21 \mathrm{kPa}$ (without bagsse ash) to $98 \mathrm{kPa}$ ( with $30 \%$ bagasse ash).

2. Quick lime $(\mathrm{CaO})$ content, $\mathrm{CaO} / \mathrm{SiO}_{2}$, and $\mathrm{CaO} /\left(\mathrm{SiO}_{2}+\mathrm{Al}_{2} \mathrm{O}_{3}\right)$ are the fundamental factors for unconfined compression strength of organic soil. The significant improvement occur on 0.25 $<\left(\mathrm{CaO} / \mathrm{SiO}_{2}\right)<1.00$, and $0.2<\mathrm{CaO} /\left(\mathrm{SiO}_{2}+\mathrm{Al}_{3} \mathrm{O}_{3}\right)$ $<0.67$. $\mathrm{CaO}$ content and qu are strongly correlated with correlation coefficient between $0.957-0.995$.

3. High organic content (OC) in the soils affects the maximum dry density (MDD) decrease the MDD. Soil Y with $13 \%$ OC, its MDD is 16.3 $\mathrm{kN} / \mathrm{m}^{3}$, soil $\mathrm{Z}$ with $18 \%$ OC its MDD is 14.8 $\mathrm{kN} / \mathrm{m}^{3}$ and soil $\mathrm{X}$ with $\mathrm{OC}(\mathrm{MDD}=11.3$ $\mathrm{kN} / \mathrm{m}^{3}$ )

4. Unconfined compression strength of original soils is proportional to their maximum dry density.

5. Addition of calcium carbide residue (CCR) to bagasse ash-soil mixtures increse significantly unconfined compression strength. The improvement was more than twice ( $93 \mathrm{kPa}$ to $208 \mathrm{kPa} 0$, on $9 \% \mathrm{CCR}$ dosage.

The Writers wish to express their gratitude to Lembaga Penelitian dan Pengabdian Pada Masyarakat (LPPM) Universitas Atma Jaya Yogyakarta for the financial support to the research group to complete the research. Special thanks is also acknowledged to the Soil Mechanics Laboratory Fakultas Teknik Universitas Atma Jaya Yogyakarta for supporting facilities to complete the research.

\section{References}

1. W. Diana \& A.S. Muntohar., Proc. Konferensi Nasional Teknik Sipil Ke-6, Univesitas Trisakti Jakarta, 33-37 (2012). [in Indonesian]

2. W. Diana \& A.S. Muntohar., Proc. Konferensi Nasional Teknik Sipil Ke-7, Univesitas Sebelas Maret Surakarta, 69-75 (2013). [in Indonesian]

3. J.T. Hatmoko, ., and Y.Lulie., Proc. Konferensi Nasional Teknik Sipil Ke-1,. Univesitas Atma Jaya Yogyakarta , 101-109 (2007). [in Indonesian]

4. S. Horpibulsuk., J. Of Mtls in Civil Egrg., ASCE, $125,470-475(2013)$

5. M. Janz, and S.E. Johnson, Report 9, Sweedish Deep Stabilization Research Center, Sweden (2012).

6. R.L. Parson, and E. Kneebone, Ground Improvement, 9 , 33-38 (2005). 
7. M.B. Hampton., and T.B. Edil., Soil Improvement for big digs (GSP 81), $\mathrm{ASCE}<$ Reston, PA (1998).

8. J.T. Hatmoko, ., and H. Suryadharma., Proc. Konferensi Nasional Teknik Sipil Ke-8,. Institut Technlogi Nasional, Bandung , 89-94 (2014). [in Indonesian]

9. Suprijono, Majalah Media Teknik, Fakultas Teknik Universitas Gadjah Mada, No.3, XVII, Desember (1995). [in Indonesian]

10. C. Gerald., Kirman, and M. Amelia., Proc. Konferensi Nasional Teknik Sipil Ke-8, Institut Teknologi Nasional, Bandung , 109-116 (2014) [in Indonesian]

11. S. Bin-Shafique, T. Edil., C. Benson, and A. Senol, Proc. ICE Geotech. Eng., 157, 239-249 (2004)

12. B.D. Trzebiatowski, T.B. Edil., and C.H. Benson, Recycled Materials in geotechnics (GSP 127), ASCE, Reston, VA 169-175 (2005).

13. J. Prabakar, R. Dendokar, and R.K. Morchale, Constr. Buil. Mater. 18, 263-267 (2004).

14. T.B. Edil, A.A. Acosta, and C.H. Benson, J. Mater. Civ. Eng., 18, 283-294 (2006).

15. H. Tremblay, J. Duchesne, J. Locat, and S. Lerouil, Can. Geotech. J., 1, 535-546 (2002).

16. K. Axelsson, S.E. Johanson, and R. Andersson, Report 3, Swedish Deep Stabilization Research Center, Sweden (2002).

17. H. Odadjima, S. Noto, J. Nishikawa, and T. Yamazaki, Proc., Int. Workshop on Engineering Characteristics and behaviour of Peat, Sapporo, Japan (1995).

18. M. Kitazume, Proc., Int. Conf. on Deep Mixing Best Practice and Recent Advanced Swedish Deep Stabilization Research Center, Sweden (2005). 